\title{
POLSKA PRASA DLA KOBIET W INTERNECIE
}

\author{
Anna Wesołowska \\ Biblioteka Wydziału Informatyki \\ i Zarządzania \\ Politechnika Wrocławska
}

Czasopisma dla kobiet, czasopisma dla kobiet online, polska prasa dla kobiet

„Prasa kobieca to grupa czasopism (przeważnie tygodniki), których profil jest kształtowany pod kątem potrzeb czytelniczych kobiet oraz ich aktualnego położenia społecznego. W czasopismach kobiecych oprócz artykułów publicystycznych, reportaży, felietonów, utworów literackich, zamieszczane są rubryki poświęcone sprawom mody, gospodarstwa domowego, problematyce rodziny i wychowania dzieci itp."1. Definicja ta jest uważana przez współczesnych badaczy za zbyt ogólną i jednostronna ${ }^{2}$, niewystarczająco bowiem wyróżnia prasę kobieca z ogółu prasy. Nie ma w niej wyraźnego zaakcentowania charakteru wydawniczo-piśmienniczego tego typu czasopism. Poza tym pomija się fakt, iż twórcami i odbiorcami prasy kobiecej nie zawsze są kobiety - 10\% ogółu czytelników to mężczyźni³.

Biorąc pod uwagę cechy prasy elektronicznej i sposób jej funkcjonowania, można wyróżnić trzy typy:

1. Prasa istniejąca wyłącznie w postaci elektronicznej, dostępna online (bezpłatnie lub odpłatnie);

2. Specjalnie przygotowane wydania online gazet i czasopism ukazujących się przede wszystkim w postaci drukowanej;

3. Prasa udostępniana online w wersji identycznej z papierowa, odpłatnie ${ }^{4}$.

Przedstawienie udziału polskich kobiecych czasopism elektronicznych online wśród uniwersum czasopism elektronicznych w Internecie nie jest łatwym zadaniem, ponieważ brakuje źródła informacji, które prezentowałoby kompletną listę tych czasopism. Niewystarczające okazują się zarówno baza ISSN w Bibliotece Narodowej, jak i przygotowywany przez Ośrodek Badań Prasoznawczych Uniwersytetu Jagiellońskiego „Katalog mediów polskich” oraz

${ }^{1}$ Encyklopedia wiedzy o prasie. Pod red. J. Maślanki. Wrocław 1976, s. 172.

2 Z. Sokół: Prasa kobieca w Polsce w latach 1945-1995. Rzeszów 1998, s. 8.

${ }^{3}$ M. Lizurej: Prasa kłamie czy wychowuje? Fenomen prasy kobiecej. W: Edukacyjne konteksty kultury popularnej. Pod red. W. Jakubowskiego, E. Zierkiewicz. Kraków 2002, s. 73.

${ }^{4}$ Słownik terminologii medialnej. Pod red. W. Pisarka. Kraków 2006, s. 155. 
inne spisy dostępne w Internecie ${ }^{5}$, na przykład nieaktualizowana już „Lista polskich czasopism elektronicznych oraz elektronicznych odpowiedników periodyków drukowanych" autorstwa Wiktora Gawareckiego ${ }^{6}$. Niejednakowe dane podawane są także w katalogach czasopism na portalach, np.: Katalog portalu Onet.pl odnotowuje 40 tytułów prasy kobiecej ${ }^{7}$, natomiast Wirtualna Polska wskazuje 45 tytułów $^{8}$, a katalog stron WWW Gazeta.pl - tylko 27 tytułów. Z kolei dział serwisu na temat prasy - Prasa Kobieca ${ }^{9}$ podaje aż 52 tytuły. Jednakże niektóre z nich są wątpliwe, np. „Bukiety”, „Lubię gotować”, „Moje mieszkanie”, „Ślub”. Według oceny własnej autorki, na koniec 2010 r. w Internecie dostępnych było 46 tytułów ${ }^{10}$ czasopism dla kobiet w wersji online, przy czym 34 ma równoległą wersję drukowana, natomiast 12 z nich ma jedynie postać online (zob. wykaz tytułów na końcu).

\section{Czasopisma dla kobiet w wersji online}

Pierwsze polskie elektroniczne czasopismo dla kobiet ukazujące się tylko w wersji online - „Kafeteria” powstało w 1999 r. w ramach rozwoju „Portalu o2”. Przełomowy dla rozwoju elektronicznych czasopism dla kobiet ukazujących się tylko w wersji online okazał się rok 2004. Powstały wówczas aż cztery nowe tytuły: „Female”, „Pinezka.pl”, „PuellaNova” oraz „Dział kobieta” w funkcjonującym od 2001 r. dzienniku internetowym Agory S. A. - „Gazeta.pl”. W 2006 r. powstały dwa nowe tytuły, a w latach 2007, 2008, 2009 i 2010 - po jednym nowym tytule. Najnowszym czasopismem tego typu jest „Allebabka”.

Polskie elektroniczne czasopisma dla kobiet ukazujące się tylko w wersji online w większości ( 7 z 12) wydawane są przez małe, zazwyczaj jednoosobowe wydawnictwa, czasem związane z prowadzoną działalnością gospodarcza - jak w przypadku „Female” czy „PuellaNova”. Zdarzają się czasopisma prowadzone amatorsko i anonimowo - jak „Babskie Story”, czy wydawane nakładem stowarzyszenia - jak w przypadku czasopisma „Pinezka.pl”. Duże wydawnictwa przeważnie mają w Internecie odpowiedniki wersji drukowanych czasopism kobiecych lub też mają działy dla kobiet w większych serwisach informacyjnych, jak w przypadku Agory S. A. - „Gazeta.pl: kobieta” czy wydawnictwa Ringer Axel

${ }^{5}$ A. Drabek, A. Pulikowski: Baza danych - „Naukowe i fachowe czasopisma elektroniczne" - stan badań. EBIB Elektroniczny Biuletyn Informacyjny Bibliotekarzy. 2006, nr 1. [online]. [dostęp: 20.12.2010]. Dostępny w World Wide Web: < http://www.ebib.info/ 2006/71/drabek.php>.

${ }^{6}$ Lista ta w 1999 r. liczyła 1065 tytułów, w tym 3 dla kobiet, w 2007 r. liczyła 1527 tytułów, w tym 7 dla kobiet. [online]. [dostęp: 20.12.2010]. Dostępny w World Wide Web: <http://www.old.inib.uj.edu.pl/archiwum/czasopisma/pol.html>.

${ }^{7}$ Katalog Onet: prasa kobieca. [online]. [dostęp: 27.12.2010]. Dostępny w World Wide Web: <http://katalog.onet.pl/112,prasa-kobieca,k.html>.

${ }^{8}$ Katalog Wp: prasa kobieca. [online]. [dostęp: 27.12.2010]. Dostępny w World Wide Web: < http://katalog.wp.pl/prasa-kobieca/>.

${ }^{9}$ Serwis Prasa kobieca. [online]. [dostęp: 27.12.2010]. Dostępny w World Wide Web: $<$ http://www.prasa.ryc.pl/kobieca/>.

${ }^{10}$ Liczba ustalona na podstawie wyników podawanych przez wyszukiwarki internetowe oraz adresów witryn czasopism zamieszczonych w katalogach internetowych oraz na stronach wydawnictw prasy kobiecej. 
Springer - „Dziennik.pl: kobieta”. Modelowy odbiorca tego typu prasy to kobieta w przedziale wiekowym 18-55 lat, z co najmniej średnim wykształceniem, mieszkająca w mieście i mająca dostęp do Internetu. Największą popularnością wśród internautów ciesza się „Gazeta.pl: kobieta” oraz „Dziennik.pl: kobieta” z dzienną liczbą wyświetleń wahająca się od kilkudziesięciu do kilkuset tysięcy. Dzieje się tak z pewnościa ze względu na markę i zaufanie do tych wydawnictw oraz poziom merytoryczny prezentowanych treści. Nie bez znaczenia jest również fakt, że są to działy stanowiące pewną część popularnych dzienników internetowych. Wśród czasopism wydawanych przez prywatne małe wydawnictwa najpopularniejsze jest „Female”, następnie „Na Obcasach” i „PuellaNova”. Ich dzienna liczba wyświetleń waha się od kilkuset do kilku tysięcy. Najmniej czytelników ma amatorskie - „Babskie Story”, mający specyficzną grupę odbiorców „Magazyn Kobiet Puszystych” oraz dopiero rozwijające się czasopismo „Allebabka”. Dziennie wyświetlane są około dziesięciokrotnie.

Czasopisma te $w$ większości mają taką samą grupę docelową odbiorców, w wyniku czego pełnia, w różnym stopniu w zależności od charakteru czasopisma, podobne funkcje: informacyjne, rozrywkowe, reklamowe, poradnicze.

Wszystkie polskie czasopisma elektroniczne dla kobiet ukazujące się tylko $w$ wersji online są tworzone w formie witryny internetowej napisanej w języku html. Atrakcyjność wyglądu czasopism jest różna. Uzależniona jest często od czasu, w którym strona powstała - im wcześniej, tym mniej atrakcyjna. Najmniej nowoczesna grafikę ma „Kobieca Linia” i „Kafeteria”, natomiast najlepszą - „Na Obcasach”, „Female” i „PuellaNova”.

Najbardziej funkcjonalny i różnorodny mechanizm wyszukiwawczy mają, ze względu na swój informacyjny charakter: „Gazeta.pl: kobieta” i „Dziennik.pl: kobieta”. Najtrudniej dotrzeć do informacji czytając: „Babskie Story”, „Kafeterię” i „Kobiecą Linię". Czasopisma te nie są wyposażone w wyszukiwarkę artykułów, newsletter, kanał RSS oraz tagi. „Babskie Story” nie ma nawet archiwum artykułów. Przyczyna jest również wiek tych stron oraz amatorskie podejście w przypadku czasopisma „Babskie Story”. Czasopisma tego typu stawiają na opinię oraz szybki i stały kontakt z czytelnikiem, dlatego tworzą fora i kluby dyskusyjne. Trzy czasopisma nie daja możliwości komentowania artykułów przez czytelników, są to: „Babskie Story”, „Kobieca Linia” i „Na Obcasach”, natomiast z forum nie mogą skorzystać czytelniczki czasopism: „Allebabka”, „Babskie Story”, „Gazeta.pl: kobieta”, „Kobieca Linia” i „KobietaMag”. Wyrazem nowoczesności jest stosowanie multimediów i akcesoriów: najwięcej multimediów ma czasopismo: „KobietaMag”, „Dziennik.pl: kobieta” i „Magazyn Kobiet Puszystych”, natomiast w największą liczbę akcesoriów zaopatrzone sa czasopisma „Female”, „PuellaNova” i „Dziennik.pl: kobieta”. Multimediów i akcesoriów nie maja: „Allebabka”, „Babskie Story”, „Kafeteria”, „Kobieca Linia” i „Pinezka”.

Wszystkie polskie czasopisma elektroniczne dla kobiet ukazujące się tylko w wersji online są bezpłatne i utrzymują się głównie z reklam. Jedynie „Pinezka” nie zamieszcza żadnej reklamy, ponieważ finansowana jest przez stowarzyszenie. Najwięcej reklam pojawia się na stronach głównych najbardziej popularnych czasopism: „Gazeta.pl: kobieta”, „Dziennik.pl: kobieta”, „Kafeteria”. Szczegóły struktury polskich czasopism elektronicznych dla kobiet ukazujących się tylko w wersji online ilustruje tabela. 
Cechy czasopism online

\begin{tabular}{|c|c|c|c|c|c|c|c|c|c|c|c|c|c|c|c|c|c|c|c|c|c|c|}
\hline 오 & $\stackrel{\bar{z}}{\gtrless}$ & 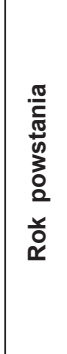 & $\frac{\frac{\pi}{d}}{\frac{N}{0}}$ & 훈 & 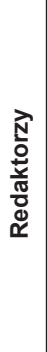 & 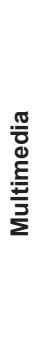 & 톤 & $\frac{E}{\frac{E}{3}}$ & $\frac{\text { 은 }}{\frac{0}{\pi}}$ & 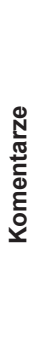 & 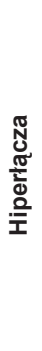 & 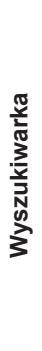 & 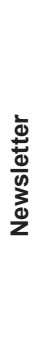 & 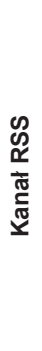 & $\frac{\text { 음 }}{\square}$ & " & 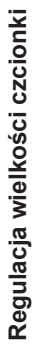 & 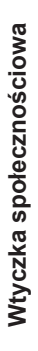 & 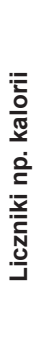 & 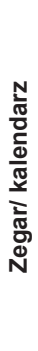 & 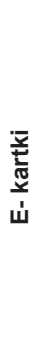 & $\frac{\overrightarrow{\frac{E}{\pi}}}{\frac{\pi}{x}}$ \\
\hline 1. & $\begin{array}{l}\text { Allebabka.pl: } \\
\text { inna strona } \\
\text { kobiety }\end{array}$ & 2010 & 10 & 10 & 3 & 0 & 0 & 1 & 0 & 1 & 1 & 1 & 0 & 0 & 0 & 0 & 0 & 1 & 0 & 0 & 0 & 8 \\
\hline 2. & $\begin{array}{l}\text { Babskie } \\
\text { Story }\end{array}$ & 2007 & 10 & 10 & 1 & 0 & 0 & 0 & 0 & 0 & 0 & 0 & 0 & 0 & 0 & 0 & 0 & 0 & 0 & 0 & 0 & 1 \\
\hline 3. & $\begin{array}{l}\text { Dziennik.pl: } \\
\text { kobieta }\end{array}$ & 2006 & 10 & $\begin{array}{r}52 \\
920 \\
\end{array}$ & - & 2 & 1 & 1 & 1 & 1 & 1 & 1 & 1 & 1 & 0 & 0 & 1 & 1 & 0 & 1 & 1 & 7 \\
\hline 4. & $\begin{array}{l}\text { Female: } \\
\text { internetowy } \\
\text { magazyn } \\
\text { kobiecy }\end{array}$ & 2004 & 15 & $\begin{array}{r}2 \\
107\end{array}$ & 4 & 0 & 1 & 1 & 1 & 1 & 1 & 1 & 1 & 1 & 1 & 1 & 0 & 1 & 1 & 0 & 0 & 2 \\
\hline 5. & $\begin{array}{l}\text { Gazeta.pl: } \\
\text { kobieta }\end{array}$ & 2004 & 11 & $\begin{array}{l}639 \\
450 \\
\end{array}$ & - & 0 & 0 & 1 & 1 & 1 & 1 & 1 & 1 & 1 & 0 & 0 & 1 & 0 & 0 & 1 & 0 & 6 \\
\hline 6. & Kafeteria.pl & 1999 & 5 & $\begin{array}{r}44 \\
290 \\
\end{array}$ & 4 & 0 & 1 & 1 & 0 & 1 & 1 & 0 & 0 & 0 & 0 & 0 & 0 & 0 & 0 & 0 & 0 & 6 \\
\hline 7. & \begin{tabular}{|l} 
Kobieca \\
Linia.pl
\end{tabular} & 2001 & 5 & 438 & 7 & 0 & 0 & 1 & 0 & 0 & 1 & 0 & 0 & 0 & 0 & 0 & 0 & 0 & 0 & 0 & 0 & 1 \\
\hline 8. & $\begin{array}{l}\text { KobietaMag. } \\
\text { pl: magazyn } \\
\text { kobiecy } \\
\text { online }\end{array}$ & 2009 & 8 & 20 & - & 1 & 0 & 1 & 1 & 1 & 1 & 1 & 1 & 1 & 0 & 1 & 0 & 1 & 0 & 0 & 1 & 3 \\
\hline 9. & $\begin{array}{l}\text { Magazyn } \\
\text { Kobiet } \\
\text { Puszystych }\end{array}$ & 2008 & 25 & 10 & 5 & 1 & 1 & 1 & 1 & 1 & 1 & 1 & 0 & 0 & 0 & 1 & 0 & 0 & 0 & 1 & 0 & 3 \\
\hline 10. & $\begin{array}{l}\text { Na } \\
\text { Obcasach: } \\
\text { magazyn dla } \\
\text { kobiet }\end{array}$ & 2006 & 8 & $\begin{array}{r}2 \\
101\end{array}$ & - & 0 & 1 & 1 & 0 & 0 & 1 & 1 & 0 & 0 & 0 & 1 & 0 & 0 & 1 & 0 & 0 & 3 \\
\hline 11. & $\begin{array}{l}\text { Pinezka.pl: } \\
\text { magazyn } \\
\text { z domieszka } \\
\text { absurdu }\end{array}$ & 2004 & 3 & 450 & $\begin{array}{l}1 \\
5\end{array}$ & 0 & 1 & 1 & 0 & 1 & 1 & 1 & 1 & 0 & 0 & 0 & 0 & 0 & 0 & 0 & 0 & 0 \\
\hline 12. & $\begin{array}{l}\text { PuellaNova: } \\
\text { internetowe } \\
\text { pismo } \\
\text { kobiece }\end{array}$ & 2004 & 15 & 967 & 6 & 0 & 1 & 1 & 1 & 1 & 1 & 1 & 0 & 0 & 0 & 0 & 0 & 1 & 1 & 1 & 1 & 1 \\
\hline
\end{tabular}

* Odbiorcy to dzienna liczba odwiedzających, dane pochodzą ze źródła: <http://bizinformacja.pl/>.

Stałe działy tych czasopism koncentruja się w większości na podobnej tematyce. Wynika to $z$ faktu, że czasopisma te w większości kierowane sa do takiej samej grupy odbiorców. Czytelniczki mogą znaleźć w nich najwięcej informacji na temat zdrowia i urody, mody, kucharstwa, kultury i książki, stylu życia, ciąży i wychowania dzieci. Istotne miejsce zajmuje tematyka zwiazzana $z$ dieta, psychologia, horoskopami, seksem. Stosunkowo mało informacji jest na tematy: astrologii (ale dużo na temat horoskopów), feminizmu (zapewne 
ta tematyka jest nieco zakamuflowana w stylu życia), poezji (ta w jakiejś mierze powinna mieścić się też w tematyce kulturalnej i książkach). Dziwić może niskie zainteresowanie praca, prawem, biznesem, co zapewne jest wynikiem stereotypu kobiety jako odbiorcy treści. Szczegóły zamieszczanej tematyki ilustruje wykres 1.

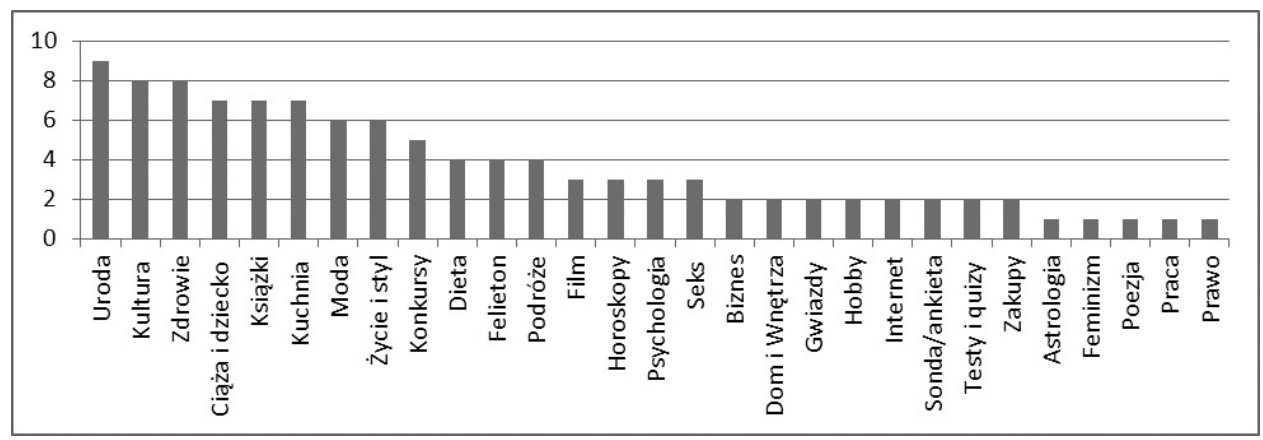

Wykres 1. Tematyka

Według opinii medioznawcy dr Doroty Piontek „czytelniczka prasy kobiecej skupia się na kwestiach stereotypowo będących domeną sfery prywatnej: rodzina, poukładany dom, szczęśliwe życie osobiste, zaspokajanie potrzeb partnera, także w sferze seksualnej. Wzorzec ten jest uniwersalny, niezależny od rodzaju prasy"11. Zaprezentowane czasopisma realizuja go w pełni, instruując czytelniczki, jak należy wyglądać, zachowywać się, jaki styl życia prowadzić, co czytać, jakie filmy ogląać, co kupować itp.

Trudno ocenić wartość merytoryczną tekstów artykułów publikowanych na łamach polskich internetowych czasopism dla kobiet. Faktem jest, że czasopisma te nie współpracują ze znanymi dziennikarzami i pisarzami.

Internet oferuje wiele witryn i serwisów z interesującymi informacjami dla kobiet. Szczególnie są to kobiece portale internetowe. Obecnie można skorzystać z 24 polskich portali dla kobiet, nie można ich jednak zaliczyć do czasopism w sposób mechaniczny. Wyjątkiem są serwisy, które są elektronicznymi odpowiednikami wydań drukowanych czasopism lub stronami internetowymi. Otrzymują one również numer ISSN, który służy do identyfikacji tytułu w światowym systemie informacji, ale przydaje się też do pozycjonowania strony wśród czasopism, podniesienia rangi pisma i ujęcia go w spisach czasopism. Kwalifikacja portalu jako czasopisma pociaga za sobą pewne konsekwencje. Jeżeli serwis zarejestrowany jest jako czasopismo, stosuje się wtedy do niego prawo prasowe. W niektórych przypadkach warto jest zarejestrować serwis internetowy jako czasopismo, na przykład aby zapobiec konkurencyjnemu wydaniu drukiem czasopisma o takim samym tytule jak serwis ${ }^{12}$.

Wobec tak dużej liczby portali, elektroniczne czasopisma kobiece ukazujące się tylko w wersji online, aby przetrwać i być opłacalnymi dla wydawcy,

11 B. Ratuszniak: Pisma kobiece stawiają na Dodę i Joannę Liszowską. [online]. [dostęp: 19.03.2011]. Dostępny w World Wide Web: <http://media2.pl/badania/54843-pismakobiece-stawiaja-na-dode-i-joanne-liszowska.html>.

12 P. Janus: Portal lub czasopismo. „Press” 2004, nr 10, s. 85-86. 
powinny, oprócz posiadania atrakcyjnego, nowoczesnego wyglądu i dobrze funkcjonującego mechanizmu wyszukiwawczego, a przede wszystkim wiarygodnych i ciekawych informacji, czymś się wyróżniać. Wskazać można tu cztery tendencje rozwojowe: kompleksowość i aktualność informacji - upodobnienie do portalu informacyjnego; oryginalność grafiki, stosowanych multimediów i przydatnych akcesoriów; wyraźne określenie tematyki i grupy docelowej odbiorców; świadczenie dodatkowych e-usług - powiązanie czasopisma z działalnością gospodarcza.

\section{Czasopisma dla kobiet w wersjach równoległych: online i drukowanej}

Niewatpliwie konkurencja dla prasy kobiecej ukazującej się tylko w wersji online jest prasa internetowa, mająca odpowiedniki drukowane. Tytuły te stanowia $3 / 4$ polskich czasopism dla kobiet w Internecie.

Pierwszy polski elektroniczny odpowiednik czasopisma dla kobiet pojawił się w 1999 r. Była to witryna internetowa czasopisma "Cosmopolitan”, którego angielska edycja miała swoją wersję elektroniczną rok wcześniej. W 1999 r. pojawiła się również witryna internetowa czasopisma „Zwierciadło”. Trzy lata później w Internecie zaczęły funkcjonować witryny „Dobrych Rad” i „Dziewczyny". Tworzone wówczas strony internetowe czasopism drukowanych miały za zadanie być ich elektronicznymi wizytówkami. Wkrótce postęp technologiczny, poprawa dostępności i obniżenie ceny Internetu umożliwiły prowadzenie stron internetowych wzbogaconych o fora, multimedia, archiwum numerów czy konta użytkowników. Przełomowy dla rozwoju polskich elektronicznych czasopism dla kobiet okazał się rok 2009. Powstało wówczas aż 10 nowych elektronicznych odpowiedników kobiecych czasopism drukowanych. W 2010 r. dynamika tworzenia tego typu medium spadła. Najnowszym czasopismem tego typu jest „EKS Magazyn". Spośród analizowanych elektronicznych odpowiedników polskich czasopism kobiecych $26 \%$ powstało równocześnie ze stworzeniem wersji drukowanej. Dwumedialność gwarantuje im większą liczbę odbiorców. Tworzenie witryny internetowej wcześniej wydawanego tylko drukiem czasopisma wiąże się również ze zmianą wydawcy, jak w przypadku czasopism: „Hot moda \& shopping”, „Kobieta i życie”, „Olivia”, „Pani Domu”, „Przyjaciółka”. Pozostałe tytuły elektronicznych odpowiedników polskich czasopism kobiecych powstały w ramach rozwoju oferty wydawniczej lub modernizacji profilu wydawniczego pisma.

Elektroniczne odpowiedniki polskich drukowanych czasopism kobiecych wydawane są głównie przez duże międzynarodowe koncerny wydawnicze (G+J Gruner+Jahr Polska Sp. z o.o. \& Co. (4 tytuły), Ringer Axel Springer Polska (1 tytuł), Hearst Marquard Publishing Sp. z o.o. (5 tytułów), Burda Media Polska Sp. z o.o. (2 tytuły), Elle Polska Sp. z o.o., Wydawnictwo Bauer Sp. z.o.o. (3 tytuły), Edipresse Polska S.A. (4 tytuły). Największa spółka wydawnicza w Polsce - Agora S. A. wydaje 3 tytuły. Elektroniczne odpowiedniki polskich drukowanych czasopism kobiecych wydawane są także przez małe polskie wydawnictwa: Elipsa Sp. z o.o., ViMedia, Press Factory, estilopress Sp. z o.o., Bruno Company, Valkea Media S.A., ID Media Polska, Wydawnictwo K Mag, Etna, Top Media Hause, Zwierciadło Sp. z o.o. 
Modelowy odbiorca tego typu prasy to, podobnie jak w czasopismach online, kobieta w przedziale wiekowym 18-55 lat, z co najmniej średnim wykształceniem, mieszkająca w mieście i mająca dostęp do Internetu. W większości sa to czytelniczki drukowanej wersji poszczególnych tytułów czasopism kobiecych. Największą liczbę wyświetleń mają witryny czasopism: „Avanti”, „Wysokie Obcasy" i "Hot : moda \& shopping”. Wysoka pozycję zapewniaja im: prezentowanie tekstów w znacznej części pochodzących z wersji drukowanej, nowoczesne rozwiązania graficzne, przyjazny interfejs. Mała popularnościa cieszą się elektroniczne odpowiedniki czasopism: „Shape”, „Sekrety Kobiet”, „Boutique”, „Dobre Rady”, „Existence”, „Exklusiv”, „Imperium Kobiet”, „In Style”, „Kobieta i życie”, „Miasto Kobiet”, „Pani”, „Twój Styl”. Każda z tych witryn ma pewne braki, na przykład nieczytelną nawigację, brak multimediów, forum, brak pełnych tekstów artykułów.

Czasopisma te pełnia, w różnym stopniu, w zależności od charakteru, podobne funkcje: informacyjne, rozrywkowe, reklamowe, poradnicze, społeczne, komunikacyjne.

Większość elektronicznych odpowiedników drukowanych polskich czasopism kobiecych jest bezpłatna. Witryny finansowane sa w ramach prowadzenia drukowanego tytułu lub utrzymują się z reklam i liczby wyświetleń. Płatne e-wydania posiadaja „Avanti”, „Wysokie Obcasy”, „Poradnik Domowy”, „EKS Magazyn”, „Zwierciadło”.

Elektroniczne odpowiedniki polskich czasopism dla kobiet sa stworzone w formie witryny internetowej napisanej w języku html oraz e-wydań. Atrakcyjność wyglądu tych czasopism jest różna i często uzależniona od wieku strony. Wydaje się, że najmniej nowoczesna grafikę witryny internetowej mają czasopisma: „Bluszcz”, „Shape” i „Dobre Rady”, natomiast najbardziej innowacyjny interfejs posiadaja witryny czasopism: „Avanti”, „Gala” i „Cosmopolitan”. W większości witryn internetowych czasopism kobiecych grafika nawiazuje do zastosowanych w drukowanej formie czasopisma kroju czcionki, kolorystyki i logotypu.

Najbardziej funkcjonalny i różnorodny mechanizm wyszukiwawczy daja witryny czasopism: „Avanti”, „Cosmopolitan”, „EKS Magazyn”, „Gala”. Użytkownicy serwisu moga uzyskać informacje o nowościach na stronie przez RSS i newsletter. Najtrudniej dotrzeć do informacji, czytając wydania internetowe „Bluszczu”, „Botique”, „e!stilo”. Czasopisma te nie są wyposażone w wyszukiwarkę artykułów, newsletter, kanał RSS oraz tagi. „Bluszcz”, „Dobre Rady”, Hot : moda \& shopping”, „Elle”, „Shape” nie maja nawet archiwum artykułów. Przyczyna jest czas utworzenia tych stron, brak ich aktualizacji i modernizacji oraz celowe zamierzenie wydawnictwa co do funkcji witryny internetowej względem czasopisma drukowanego. Witryny nieposiadające dodatkowych elementów, takich jak forum, archiwum artykułów czy multimedia, mogą być jedynie wizytówkami czasopisma drukowanego.

Nowoczesne witryny czasopism posiadają w większości takie elementy jak: multimedia (36\%), archiwum (85\%), forum (79\%'), możliwość oceniania artykułów i zamieszczania komentarzy (47\%) oraz prowadzenie blogu (24\%). Zamierzeniem wydawców prowadzących takie usługi jest stworzenie społeczności czytelniczek danego czasopisma, a także samej witryny. Ułatwiony jest 
tu stały i szybki kontakt z czytelniczkami, które mogą na bieżąco wypowiadać swoje opinie na temat artykułów, zamieszczać sugestie itp.

Czasopisma zamieszczają reklamy. Najwięcej pojawia się na stronach głównych najbardziej popularnych czasopism. Reklamy nie występują na stronach internetowych „Dobrych Rad” i „InStyle”. Szczegóły struktury elektronicznych odpowiedników polskich czasopism dla kobiet ilustruje tabela 2.

Tabela 2

Cechy czasopism w wersji równoległej: online i drukowanej

\begin{tabular}{|c|c|c|c|c|c|c|c|c|c|c|c|c|c|c|c|c|c|c|}
\hline$\dot{9}$ & $\stackrel{\bar{z}}{\gtrless}$ & 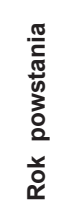 & 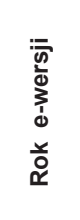 & $\frac{\frac{\lambda}{\pi}}{\frac{\pi}{N}}$ & 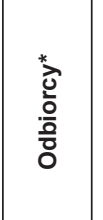 & 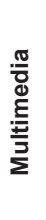 & 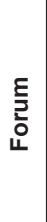 & 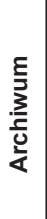 & 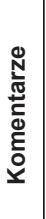 & 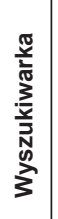 & 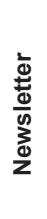 & 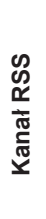 & $\frac{\delta}{0}$ & 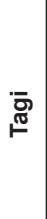 & 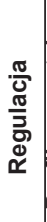 & 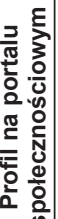 & 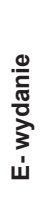 & 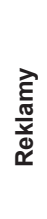 \\
\hline 1. & Avanti & 2004 & 2004 & 5 & 19805 & 1 & 1 & 1 & 1 & 1 & 1 & 1 & 0 & 1 & 1 & 1 & 1 & 9 \\
\hline 2. & Bluszcz & 2008 & 2008 & 5 & 150 & 0 & 1 & 0 & 0 & 0 & 0 & 0 & 0 & 0 & 0 & 1 & 0 & 1 \\
\hline 3. & Boutique & 2004 & 2004 & 10 & 10 & 0 & 0 & 1 & 0 & 0 & 0 & 0 & 0 & 0 & 0 & 0 & 0 & 2 \\
\hline 4. & Claudia & 1991 & 2008 & 9 & 10503 & 1 & 1 & 1 & 1 & 1 & 0 & 0 & 0 & 0 & 1 & 1 & 0 & 3 \\
\hline 5. & Cosmopolitan & 1997 & 1999 & 8 & 657 & 1 & 1 & 1 & 1 & 1 & 1 & 0 & 0 & 1 & 0 & 0 & 0 & 3 \\
\hline 6. & Dobre Rady & 1997 & 2002 & 4 & 10 & 0 & 0 & 0 & 0 & 0 & 0 & 0 & 0 & 0 & 0 & 0 & 0 & 0 \\
\hline 7. & Dziewczyna & 1991 & 2002 & 5 & 10 & 0 & 1 & 1 & 0 & 1 & 0 & 0 & 0 & 0 & 0 & 0 & 0 & 8 \\
\hline 8. & Eks Magazyn & 2010 & 2010 & 6 & 438 & 1 & 1 & 1 & 1 & 1 & 1 & 1 & 1 & 0 & 0 & 1 & 1 & 2 \\
\hline 9. & Elle & 1994 & 2009 & 1 & 1095 & 0 & 0 & 0 & 0 & 0 & 0 & 0 & 0 & 0 & 0 & 1 & 1 & 1 \\
\hline 10. & E!stilo & 2008 & 2008 & 8 & 219 & 0 & 0 & 1 & 0 & 1 & 0 & 0 & 0 & 0 & 0 & 1 & 0 & 4 \\
\hline 11. & Existence & 2009 & 2009 & 8 & 10 & 1 & 1 & 1 & 0 & 1 & 0 & 0 & 0 & 0 & 0 & 1 & 0 & 2 \\
\hline 12. & Exklusiv & 2003 & 2006 & 5 & 10 & 0 & 1 & 1 & 0 & 1 & 0 & 0 & 1 & 0 & 0 & 1 & 0 & 0 \\
\hline 13. & Gala & 2001 & 2003 & 8 & 3301 & 1 & 1 & 1 & 1 & 1 & 1 & 0 & 0 & 1 & 1 & 1 & 0 & 3 \\
\hline 14. & Glamour & 2003 & 2007 & 3 & 219 & 0 & 0 & 1 & 0 & 0 & 0 & 0 & 0 & 0 & 0 & 1 & 0 & 1 \\
\hline 15. & $\begin{array}{l}\text { Hot: moda \& } \\
\text { shopping }\end{array}$ & 2006 & 2009 & 6 & 10076 & 1 & 1 & 0 & 0 & 0 & 0 & 0 & 0 & 0 & 0 & 1 & 0 & 2 \\
\hline 16. & $\begin{array}{l}\text { Imperium } \\
\text { Kobiet }\end{array}$ & 2010 & 2010 & 6 & 10 & 0 & 0 & 1 & 0 & 1 & 1 & 0 & 0 & 0 & 0 & 1 & 0 & 2 \\
\hline 17. & In Style & 2008 & 2008 & 1 & 10 & 0 & 0 & 1 & 0 & 0 & 0 & 0 & 0 & 0 & 0 & 1 & 1 & 0 \\
\hline 18. & Joy & 2006 & 2010 & 8 & 300 & 1 & 1 & 1 & 1 & 1 & 1 & 0 & 1 & 0 & 0 & 0 & 0 & 1 \\
\hline 19. & K Mag & 2009 & 2009 & 4 & 876 & 1 & 1 & 1 & 1 & 1 & 1 & 0 & 1 & 0 & 0 & 1 & 1 & 2 \\
\hline 20. & Kobieta i Życie & 2008 & 2008 & 9 & 10 & 1 & 1 & 1 & 1 & 1 & 1 & 1 & 0 & 0 & 1 & 0 & 0 & 3 \\
\hline 21. & Miasto Kobiet & 2004 & 2004 & 7 & 10 & 1 & 1 & 1 & 1 & 1 & 1 & 0 & 0 & 0 & 0 & 1 & 1 & 2 \\
\hline 22. & Naj magazyn & 1994 & 2010 & 3 & 10503 & 1 & 1 & 1 & 1 & 1 & 0 & 0 & 0 & 0 & 1 & 1 & 0 & 3 \\
\hline 23. & Oliwia & 1998 & 2006 & 9 & 300 & 1 & 1 & 1 & 1 & 1 & 1 & 1 & 0 & 0 & 0 & 1 & 0 & 4 \\
\hline 24. & Pani & 1991 & 2010 & 13 & 10 & 1 & 1 & 1 & 0 & 1 & 1 & 1 & 1 & 0 & 0 & 0 & 0 & 2 \\
\hline 25. & Pani Domu & 1994 & 2009 & 4 & 39910 & 0 & 1 & 1 & 1 & 1 & 1 & 0 & 0 & 1 & 0 & 0 & 0 & 3 \\
\hline 26. & \begin{tabular}{|l|}
$\begin{array}{l}\text { Poradnik } \\
\text { domowy }\end{array}$ \\
\end{tabular} & 1990 & 2003 & 7 & $\begin{array}{r}2632 \\
861\end{array}$ & 1 & 1 & 1 & 1 & 1 & 1 & 1 & 0 & 0 & 1 & 0 & 1 & 2 \\
\hline
\end{tabular}




\begin{tabular}{|l|l|r|r|r|r|r|r|r|r|r|r|r|r|r|r|r|r|r|}
\hline 27. & Przyjaciólka & 1948 & 2009 & 4 & 39910 & 0 & 1 & 1 & 1 & 1 & 1 & 0 & 0 & 1 & 0 & 0 & 0 & 3 \\
\hline 28. & Sekrety Kobiet & 2006 & 2006 & 4 & 10 & 0 & 1 & 1 & 0 & 0 & 0 & 0 & 0 & 0 & 0 & 1 & 1 & 10 \\
\hline 29. & Shape & 2000 & 2009 & 4 & 10 & 0 & 1 & 0 & 0 & 0 & 0 & 0 & 0 & 0 & 0 & 0 & 0 & 1 \\
\hline 30. & Twój Styl & 1990 & 2010 & 13 & 10 & 1 & 1 & 1 & 0 & 1 & 1 & 1 & 1 & 0 & 0 & 0 & 0 & 2 \\
\hline 31. & $\begin{array}{l}\text { Uroda: beauty } \\
\text { expert }\end{array}$ & 2002 & 2009 & 4 & 39910 & 0 & 1 & 1 & 1 & 1 & 1 & 0 & 0 & 1 & 0 & 1 & 0 & 3 \\
\hline 32. & Viva & 1997 & 2009 & 7 & 39910 & 1 & 1 & 1 & 1 & 1 & 1 & 0 & 0 & 0 & 0 & 0 & 0 & 3 \\
\hline 33. & $\begin{array}{l}\text { Obsokie } \\
\text { Obcasy }\end{array}$ & 1999 & 2009 & 10 & 16054 & 1 & 1 & 1 & 0 & 1 & 1 & 1 & 1 & 0 & 1 & 1 & 1 & 8 \\
\hline 34. & Zwierciadło & 1957 & 1999 & 6 & 2101 & 1 & 1 & 1 & 0 & 1 & 1 & 1 & 1 & 0 & 0 & 0 & 1 & 2 \\
\hline
\end{tabular}

* Odbiorcy to dzienna liczba odwiedzających dane pochodzą ze źródła: <http://bizinformacja.pl/>.

E-wydanie charakteryzuje się tym, że odwzorowuje wygląd tradycyjnego wydawnictwa ciagłego, mając jednocześnie praktyczne funkcje takie jak: możliwość powiększenia stopnia czcionki i obrazu, zaznaczenia wybranych fragmentów tekstu, pełnotekstowego przeszukiwania, interaktywny spis treści, bezpośrednie przenoszenie się do innych witryn WWW opisanych w tekstach za pomocą linków.

Wersje elektroniczne początkowo tworzono w celu uzupełnienia wersji tradycyjnej. Wydanie drukowane ma znaczący wpływ na wyglad (grafika, kolorystyka, logotyp) i zawartość wersji elektronicznej. W zależności od zamierzenia wydawcy, elektroniczne odpowiedniki drukowanych czasopism kobiecych przyjmują różne sposoby publikacji materiałów pochodzących z wersji drukowanej: niektóre witryny internetowe zamieszczaja jedynie reklamę czasopisma drukowanego w postaci okładki i spisu treści aktualnego numeru, inne oprócz tego zamieszczają wstęp, fragmenty lub pełne teksty artykułów, a nawet całe numery archiwalne. W większości przypadków wydawcy decydują się na opublikowanie okładki (35\%), spisu treści (28\%) i kilku pełnych, często najlepszych artykułów (28\%). Robią to w celu zaprezentowania potencjalnemu czytelnikowi profilu wydawniczego pisma, jego aktualnej oferty, poziomu merytorycznego artykułów i zachęcenia go do kupna wydania drukowanego.

Elektroniczne odpowiedniki polskich drukowanych czasopism kobiecych wciąż się rozwijaja, pełniąc dodatkowe funkcje wobec czasopisma drukowanego. Z kolei czasopisma drukowane reklamują wersję elektroniczną czasopisma, głównie przez zamieszczanie adresu internetowego na okładce, we wstępie, spisie treści, żywej paginie, stopce redakcyjnej, tytułach stałych działów. Niektóre czasopisma zachęcają do odwiedzin witryny internetowej poprzez publikowanie reklamy, fragmentów sondy, forum lub tekstów pochodzących z wersji elektronicznej. Niekiedy czasopisma drukowane skierowują do regulaminów konkursów, zamieszczonych jedynie na stronie internetowej czasopisma. Wersja elektroniczna wywiera również wpływ na zmianę szaty graficznej i układu typograficznego drukowanego czasopisma.

Główne, stałe działy elektronicznych odpowiedników polskich drukowanych czasopism dla kobiet są uproszczone w stosunku do działów w wydaniu tradycyjnym. Przeważnie jest ich mniej i mają skrócone nazwy, ze względu na ułatwienie wyszukiwania konkretnych artykułów. Główne, stałe działy wydań internetowych koncentrują się w większości na podobnej tematyce. Wynika 
to z faktu, że czasopisma te w większości mają taką samą grupę docelową odbiorców. Czytelniczki mogą znaleźć w nich najwięcej informacji na temat mody, urody, zdrowia i kuchni. Szczegóły tematyki ilustruje wykres 2.

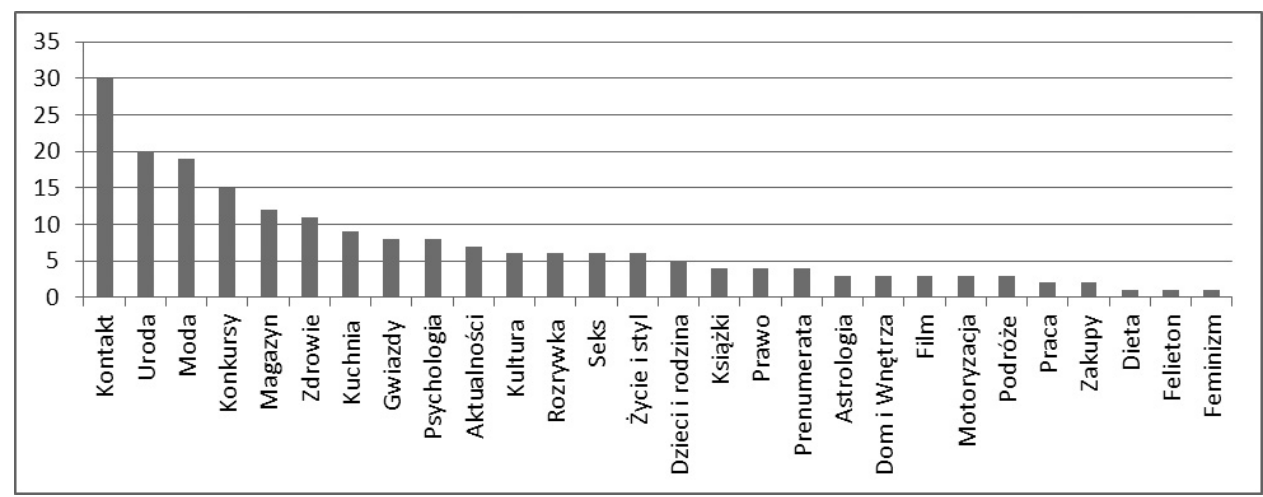

Wykres 2. Tematyka

Wartość merytoryczna tekstów artykułów prezentowanych na łamach wydań internetowych polskich czasopism kobiecych jest taka sama jak wydania drukowanego. Elektroniczne odpowiedniki prezentuja w dużej mierze te same teksty publikowane wcześniej lub mające się ukazać jednocześnie w wersji drukowanej. Teksty do obydwu wersji są pisane przez tych samych dziennikarzy.

Od 2009 r. można zauważyć tendencję do przynależności elektronicznych odpowiedników polskich drukowanych czasopism kobiecych do większych portali internetowych jak Onet, Interia, Gazeta.pl, Kobieta.pl. Wydawcy decyduja się na takie rozwiązanie ze względu na korzyści płynące z większej liczby wyświetleń oraz promocji czasopisma na znanym portalu. Koncepcja ta ma jednak wiele wad. Brak autonomicznej strony i jednocześnie przynależność do większego portalu wymusza na czasopiśmie podporządkowanie się wymogom portalu dotyczącym wyglądu artykułów i grafiki, nazw działów, nawigacji, multimediów, archiwum, lokalizacji artykułów, które znajduja się w zasobach całego portalu, a nie tytułu czasopisma. Kolejnym zagrożeniem jest konkurencja innych czasopism współtworzących portal. Istnieje również problem z określeniem liczby wyświetleń dotyczącej jednego tytułu czasopisma współtworzącego portal.

Podsumowując, w ostatnich 12 latach dokonało się wiele zmian w sektorze prasy kobiecej. Stało się tak głównie za sprawą powstania jej wersji elektronicznej. Dominuje jednak wersja drukowana, a rola wersji elektronicznej wobec wydania drukowanego jest podrzędna. Internetowe wydanie w większości ma za zadanie uzupełniać i promować wersję drukowana. Wersja elektroniczna jednak wciąż się rozwija i wywiera coraz większy wpływ na wersję drukowana. Postęp technologiczny pozwala wprowadzać do wersji elektronicznej nowe funkcje (archiwizacja, multimedialność, komunikatywność). W przyszłości wersja elektroniczna czasopism dla kobiet zapewne rozwinie się w kierunku interaktywnych i multimedialnych e-wydań i portali społecznościowych. Korzyści płynące z równoległego publikowania tekstów w gazecie drukowanej i Internecie to nie tylko profity finansowe z reklam, ze sprzedaży e-wydania 
w formacie PDF, ale także autoreklama czasopisma, łatwy kontakt z czytelnikami umożliwiający między innymi tworzenie społeczności czasopisma, czyli stałej klienteli, możliwość szybkiego poznania opinii czytelnika na temat artykułu. W przyszłości czasopisma elektroniczne dla kobiet będa mogły konkurować z wersją drukowaną. Zapewne też w większości przypadków staną się płatne i będą sprzedawane w cenie wersji drukowanej.

\section{Alfabetyczny wykaz czasopism dla kobiet online (niemających wersji drukowanej)}

„Allebabka.pl: inna strona kobiety” dziennik, red. Andrzej Andrzejczak, 2010, nr 1. [online]. Dostępny w World Wide Web: <http://www.allebabka.pl/stopka-redakcyjna>.

„BabskieStory” Wrocław, prot Hosting - Serwery, 2007, nr 1. [online]. Dostępny w World Wide Web: <http://babskiestory.pl/index.php>.

„Dziennik.pl: kobieta” dziennik, INFOR Biznes, Ringer Axel Springer Polska, Warszawa, 2006, nr 1. [online]. Dostępny w World Wide Web: <http://kobieta.dziennik.pl/>.

„Female: internetowy magazyn kobiecy” dziennik, red. Natalia Tyszka, Sopot, Herbert Grossfuss Media, 2004, nr 1. [online]. Dostępny w World Wide Web: <http://www.female.pl/>.

„Gazeta.pl: kobieta” dziennik, Agora S. A., Warszawa, 2004, nr 1. [online]. Dostępny w World Wide Web:<http://kobieta.gazeta.pl/kobieta/0,0.html>.

„Kafeteria.pl” dziennik, red. Magda Trawińska-Gosik, Warszawa, Grupa o2 Sp. z o.o., 1999, nr 1. [online]. Dostępny w World Wide Web: <http://www.kafeteria.pl/>.

„Kobieca Linia.pl” tygodnik, red. Eliza Książczak, Usługi Komputerowe s. c. \& Eliza Książczak, 2001, nr 1. [online]. Dostępny w World Wide Web: <http://kobieca.linia.pl/>.

„KobietaMag.pl: magazyn kobiecy online” dziennik, WordPress, 2009, nr 1. [online]. Dostępny w World Wide Web: <http://kobietamag.pl/>.

„Magazyn Kobiet Puszystych” dziennik, red. Dorota Zgutka, Łódź, Dorota Zgutka, 2008, nr 1. [online]. Dostępny w World Wide Web: <http://www.kobietapuszysta.pl.

„Na Obcasach: magazyn dla kobiet” dziennik, Wrocław, Kwiatkowski Media Networks MCS Studios, 2006, nr 1. [online]. Dostępny w World Wide Web: <http://www.naobcasach. $\mathrm{pl} />$.

„Pinezka.pl: magazyn z domieszką absurdu” dwumiesięcznik, red. Aleksandra Bartelska, Warszawa, Stowarzyszenie Pinezka, 2004, nr 1. [online]. Dostępny w World Wide Web: $<$ http://www.pinezka.pl/>.

„PuellaNova: internetowe pismo kobiece” dziennik, red. Aleksandra Zumkowska-Pawłowicz, Elblag, Meritum Media, 2004, nr 1. [online]. Dostępny w World Wide Web: <http:// www.puellanova.pl/>.

\section{Alfabetyczny wykaz drukowanych czasopism dla kobiet i ich elektronicznych odpowiedników w Internecie}

„Avanti: idziemy na zakupy!”, dwumiesięcznik, red. Anna Jabłońska, Warszawa, Agora, 2004, nr 1, ISSN 1732-0305.

„Avanti” [online]. Dostępny w World Wide Web: <http://www.avanti24.pl/moda/0,0.html>.

„Bluszcz”, miesięcznik, red. Rafał Bryndal, Warszawa, Elipsa Sp.z.o.o., 2008, nr 1, ISSN 1899-1378.

„Bluszcz" [online]. Dostępny w World Wide Web: <http:/www. bluszcz.com.pl>.

„Boutique: kobiecy przedmiot pożądania”, miesięcznik, red. Anna Michałowska-Ziegler, Warszawa, ViMedia, 2004, nr 1, ISSN 1733-1951. 
"Boutique" [online]. Dostępny w World Wide Web: <http:/www.boutique.com.pl>.

"Claudia”, miesięcznik, red. Justyna Szawdyn, Warszawa, Axel Ganz, Andreas Tilk Gru-

ner Jahr Polska Sp. z o.o., 1991, nr 1, ISSN 1230-8609.

„Claudia” [online]. Dostępny w World Wide Web: <http://www.kobieta.pl/magazyny/ claudia/>.

„Cosmopolitan”, miesięcznik, red. Elżbieta Smoleńska, Warszawa, Hearst Marquard Publishing Sp. z o.o., 1997, nr 1, ISSN 1428-2542.

„Cosmopolitan" [online]. Dostępny w World Wide Web: <http:/www.cosmo.pl>.

"Dobre Rady", miesięcznik, red. Anna Mandes-Tarassov, Warszawa, Hubert Burda Media, 1997, nr 1, ISSN 1643-8264.

„Dobre Rady” [online]. Dostępny w World Wide Web: <http://www.dobrerady.pl>.

„Dziewczyna”, miesięcznik, red. Andrzej Gumulak, Warszawa, Ringer Axel Springer Polska, 1991, nr 1, ISSN 1230-8153.

„Dziewczyna” [online]. Dostępny w World Wide Web: <http://www.dziewczyna.pl/>.

„EKS magazyn: kobiety chcą bardziej”, dwumiesięcznik, red. Aneta Zadroga, Kraków, Press Factory, 2010, nr 1, ISSN 2081-9526.

„EKS magazyn: kobiety chca bardziej” [online]. Dostępny w World Wide Web: <http:// www.eksmagazyn.pl>.

„Elle”, miesięcznik, red. Maria Majdrowicz-Pijanowska, Warszawa, Elle Polska Sp. z o. o., 1994, nr 1, ISSN 1232-8308.

„Elle” [online]. Dostępny w World Wide Web: <http://www.elle.pl>.

„E!stilo", dwumiesięcznik, red. Elizabet Tomaszewicz, Warszawa, estilopress Sp. z o.o., 2008, nr 1, ISSN 1899-9662.

„E!stilo" [online]. Dostępny w World Wide Web: <http://www.estilopress.com/>.

„Existence: pop \&life style magazine”, kwartalnik, red. Tomasz Kin, Warszawa, Bruno Company, 2009, nr 1, ISSN 1689-7145.

„Existence: pop \&life style magazine” [online]. Dostępny w World Wide Web: <http:// existencemag.pl/>.

„Exklusiv”, miesięcznik, red. Sławomir Belina, Warszawa, Wydawnictwo Valkea Media S. A., 2003, nr 1, ISSN 1731-6642.

„Exklusiv" [online]. Dostępny w World Wide Web: <http://www.exklusiv.pl/>.

"Gala”, tygodnik, red. Iza Bartosz, Warszawa, Axel Ganz, Andreas Tilk Gruner Jahr

Polska Sp. z o.o., 2001, nr 1, ISSN 1642-5626.

"Gala" [online]. Dostępny w World Wide Web: <http:/www.gala.pl>.

"Glamour", miesięcznik, red. Grażyna Olbrych, Warszawa, G+J Polska, 2003, nr 1, ISSN 1730-2781.

„Glamour" [online]. Dostępny w World Wide Web: <http:/www.glamour.pl>.

„Hot: moda \& shopping”, miesięcznik, red. Joanna Góra, Warszawa, Marquad Media Polska, 2006, nr 1, ISSN 1734-2929.

„Hot: moda \& shopping” [online]. Dostępny w World Wide Web: <http://hotmoda.streemo. $\mathrm{pl} /$ Community/Default.aspx>.

„Imperium Kobiet”, miesięcznik, red. Ilona Adamska, Sanok, ID Media Polska, 2010, nr 1, ISSN 1895-6858.

„Imperium Kobiet”, [online]. Dostępny w World Wide Web: <http://www.ikmagazine.pl/ info/imperium_kobiet/>.

„In Style”, miesięcznik, red. Piotr Zachara, Warszawa, Burda Communications, 2008, nr 1, ISSN 1898-8806.

„In Style” [online]. Dostępny w World Wide Web: <http:/ instyle.pl>.

"Joy", miesięcznik, red. Anna Ibisz, Warszawa, Hearst Marquard Publishing Sp. z o.o., 2006, nr 1, ISSN 1895-6343.

„Joy" [online]. Dostępny w World Wide Web: <http://joy.pl/Community/Default.aspx?Communityld=8805>.

„K Mag: kulturalna sztuka”, miesięcznik, red. Mikołaj Komar, Warszawa, Wydawnictwo K Mag, 2009, nr 1, ISSN 1899-9891.

„K Mag : kulturalna sztuka” [online]. Dostępny w World Wide Web: < http://www.kmag.pl/>. 
„Kobieta i Życie”, miesięcznik, red. Małgorzata Borzymińska, Warszawa, Bauer, 2008, nr 1, ISSN 0023-2548.

„Kobieta i Życie”[online]. Dostępny w World Wide Web: <http://kobieta.interia.pl/raport/ kobietaizycie>.

„Miasto Kobiet”, dwumiesięcznik, red. Aneta Pondo, Warszawa, Etna, 2004, nr 1, ISSN 1733-1536.

„Miasto Kobiet” [online]. Dostępny w World Wide Web: <http:/miastokobiet.pl>.

„Naj magazyn”, tygodnik, red. Jolanta Orłowska, Warszawa, G+J Polska, 1994, nr 1, ISSN 1232-7654.

„Naj magazyn” [online]. Dostępny w World Wide Web: <http:/www.naj.kobieta.pl>.

"Olivia", miesięcznik, red. Ewa Wagner, Warszawa, Hearst Marquard Publishing Sp. z o.o., 1998, nr 1, ISSN 1429-6950.

„Olivia” [online]. Dostępny w World Wide Web: <http://olivia.pl/Community/Default. aspx?Communityld=528>.

„Pani”, miesięcznik, red. Małgorzata Domagalik, Warszawa, Wydawnictwo Bauer, 1991, nr 1, ISSN 1230-8293.

„Pani” [online]. Dostępny w World Wide Web: <http://www.styl.pl/pani>.

„Pani Domu”, tygodnik, red. Urszula Zubczyńska, Warszawa, Edipresse, 1994, nr 1, ISSN 1232-8502.

„Pani Domu” [online]. Dostępny w World Wide Web: <http://polki.pl/panidomu.html>.

„Poradnik Domowy”, miesięcznik, red. Dorota Zabrodzka, Warszawa, Agora S. A., 1990, nr 1, ISSN 0867-2229.

„Poradnik Domowy” [online]. Dostępny w World Wide Web: <http://kobieta.gazeta.pl/ poradnik-domowy/0.0.html>.

„Przyjaciółka”, dwutygodnik, red. Urszula Zubczyńska, Warszawa, Edipresse Polska S. A., 1948, nr 1, ISSN 0033-2534.

„Przyjaciółka” [online]. Dostępny w World Wide Web: <http:/www.przyjaciolka.pl>.

"Sekrety Kobiet”, miesięcznik, red. Tomasz Maciejczyk, Opole, Top Media Hause, 2006, nr 1.

"Sekrety Kobiet” [online]. Dostępny w World Wide Web: <http:/www.sekretykobiet.com.pl>.

„Shape”, miesięcznik, red. Joanna Góra, Warszawa, Hearst Marquad Publishing Sp. z o.o., 2000, nr 1, ISSN 1509-8834.

„Shape” [online]. Dostępny w World Wide Web: <http:/www.shape.pl>.

"Twój Styl”, miesięcznik, red. Jacek Szmidt, Warszawa, Wydawnictwo Bauer, 1990, nr 1, ISSN 0867-1826.

"Twój Styl” [online]. Dostępny w World Wide Web: <http://www.styl.pl/>.

„Uroda: beauty expert”, miesięcznik, red. Danuta Bybrowska, Warszawa, Edipresse, 2002, nr 1, ISSN 0500-7194.

„Uroda: beauty expert” [online]. Dostępny w World Wide Web: <http://polki.pl/uroda_beauty_expert.html>.

„Viva!”, dwutygodnik, red. Katarzyna Przybyszewska, Warszawa, Edipresse Polska, 1997, nr 1, ISSN 1426-9554.

„Viva!” [online]. Dostępny w World Wide Web: <http:/www.viva.pl>.

„Wysokie Obcasy”, tygodnik, red. Ewa Wieczorek, Warszawa, Agora S. A., 1999, nr 1, ISSN 1506-9087.

„Wysokie Obcasy” [online]. Dostępny w World Wide Web: <http:/www.wysokieobcasy.pl>. „Zwierciadło”, miesięcznik, red. Manana Chyb, Warszawa, Zwierciadło Sp. z o.o., 1957, nr 1, ISSN 0514-0994.

„Zwierciadło” [online]. Dostępny w World Wide Web: <http:/www.zwierciadlo.pl>.

\section{Bibliografia}

1. Bizinformacja. [online]. Dostępny w World Wide Web: <http://bizinformacja.pl/>.

2. Drabek A., Pulikowski A.: Baza danych - „Naukowe i fachowe czasopisma elektroniczne" - stan badań. EBIB Elektroniczny Biuletyn Informacyjny Bibliotekarzy. 2006, nr 1. [online]. Dostępny w World Wide Web: <http://www.ebib.info/2006/71/drabek.php>. 
3. Encyklopedia wiedzy o prasie. Pod red. J. Maślanki. Wrocław 1976.

4. Gawarecki W.: Lista polskich czasopism elektronicznych oraz elektronicznych odpowiedników periodyków drukowanych. [online]. Dostępny w World Wide Web: <http://www. old.inib.uj.edu.pl/archiwum/czasopisma/pol.html>.

5. Katalog Onet: prasa kobieca. [online]. Dostępny w World Wide Web: <http://katalog. onet.pl/112,prasa-kobieca,k.html>.

6. Katalog Wp: prasa kobieca. [online]. Dostępny w World Wide Web: <http://katalog.wp.pl/ prasa-kobieca/>.

7. Lizurej M.: Prasa kłamie czy wychowuje? Fenomen prasy kobiecej. W: Edukacyjne konteksty kultury popularnej. Pod red. W. Jakubowskiego, E. Zierkiewicz, Kraków 2002, s. 73.

8. Media: PWN leksykon. Pod red. E. Banaszkiewicz-Zygmunt. Warszawa 2000.

9. Ratuszniak B.: Pisma kobiece stawiają na Dodę i Joannę Liszowską. [online]. Dostępny w World Wide Web: <http://media2.pl/badania/54843-pisma-kobiece-stawiaja-na-dodei-joanne-liszowska.html>.

10. Serwis Prasa kobieca. [online]. Dostępny w World Wide Web: <http://www.prasa.ryc. $\mathrm{pl} / \mathrm{kobieca} />$.

11. Słownik terminologii medialnej. Pod red. W. Pisarka. Kraków 2006.

12. Sokół Z.: Prasa kobieca w Polsce w latach 1945-1995. Rzeszów 1998.

\section{Summary}

The article describes Polish journals for women either in electronic version only or published both in electronic and print versions. The author discusses topics of articles, profile, and potential readers. She indicates dependencies between print and electronic versions of the same titles. 